\section{FOLKTALES OF INDIA}

Edited by BRENDA E. F. BECK,

PETER J. ClAUS,

PRAPHULLADATTA GOSWAMI, and JAWAHARLAL HANDOO

With a Foreword by A. K. Ramanujan

Cloth \$29.95 390 pages

8 halftones, 1 map

Folktales of the World

\section{THE SHOOTING PARTY}

A Novel

ANTON CHEKHOV

With an Introduction by Julian Symons

Paper $\$ 8.95220$ pages

\section{HAPPY HOUR}

ALAN SHAPIRO

Paper $\$ 7.9556$ pages

Library cloth edition $\$ 16.00$

Phoenix Poets

\section{ANOTHER KIND \\ OF TRAVEL \\ PAUL LAKE}

Paper $\$ 7.95$ (est.) 56 pages (est.) Library cloth edition $\$ 16.00$ (est.)

Phoenix Poets

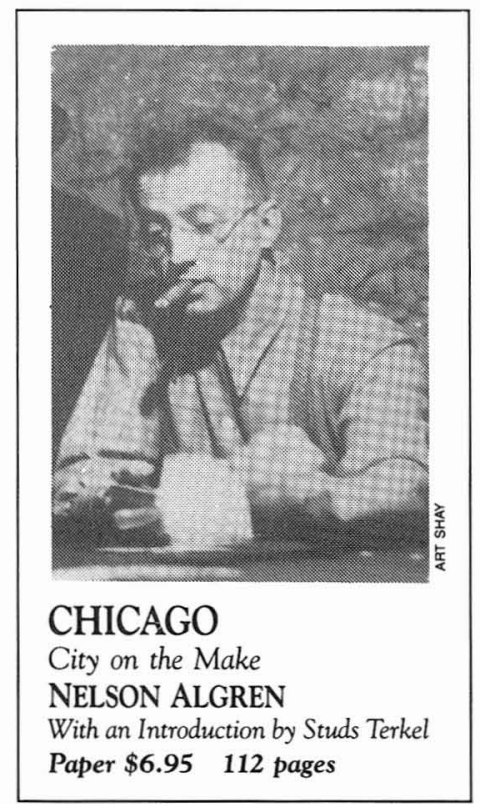

\section{GOLK}

RICHARD STERN

With a Foreword by Bernard F. Rodgers, Jr.

Paper $\$ 9.95224$ pages

Phoenix Fiction

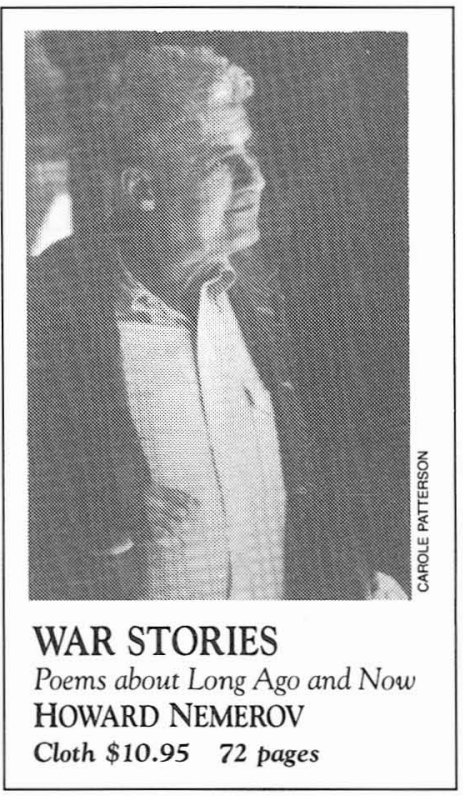

\section{NEW \& SELECTED}

POEMS, 1940-1986

KARL SHAPIRO

Paper \$9.95 112 pages (est.)

\section{POLITICS AND}

\section{POETIC VALUE}

Edited by ROBERT VON HALLBERG

Paper \$14.95 360 pages (est.)

Library cloth edition $\$ 30.00$

\section{SEX AND}

\section{SCIENTIFIC INQUIRY}

Edited by SANDRA HARDING and

JEAN F. O'BARR

Paper $\$ 10.95328$ pages

Library cloth edition $\$ 25.00$
THE UNIVERSITY

\section{OF CHICAGO}

\section{SPANISH DICTIONARY}

Fourth Edition

Revised and Enlarged by

D. LINCOLN CANFIELD

Cloth $\$ 19.95$ Paper $\$ 6.95$

484 pages 4 maps

Chicago Guides to Writing,

Editing, and Publishing -

A new edition

A MANUAL FOR WRITERS OF TERM PAPERS, THESES, AND DISSERTATIONS

Fifth Edition

KATE L. TURABIAN

Revised and Expanded by

Bonnie Birtwistle Honigsblum

Cloth $\$ 20.00$ Paper $\$ 7.95$

310 pages 9 tables, 26 line drawings

\section{CHICAGO GUIDE}

\section{TO PREPARING}

ELECTRONIC

\section{MANUSCRIPTS}

For Authors and Publishers

Prepared by the

Staff of the University of Chicago Press

Paper \$9.95 156 pages

Library cloth edition $\$ 25.00$

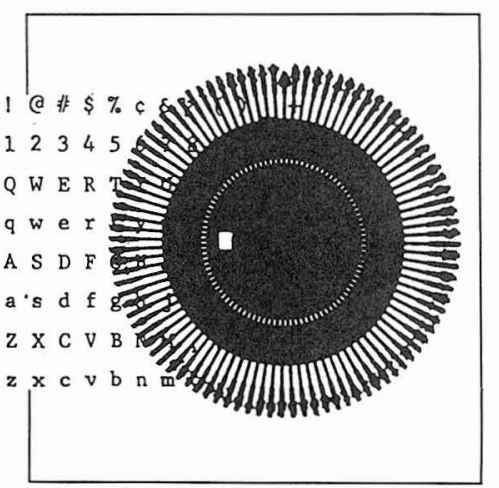

JOURNALS ON DISPLAY

- ClASSICAL PHILOLOGY

- CRITICAL INQUIRY

- MODERN PHILOLOGY

- SIGNS 


\section{Criticism \\ and Interpretation from Cornell

\section{CULTURE AND DOMINATION}

By JOHN BRENKMAN. "it is extremely heartening for literary studies that so comprehensive and serious a work of social thought finds literature worth so much of its serious attention, that the aesthetic stands along with the social and the psychoanalytic as an area of life-practice demanding investigation."-Jonathan Arac, Columbia University. $\$ 24.95$

\section{HISTORY, POLITICS, AND THE NOVEL}

By DOMINICK LaCAPRA. History and the study of literature have grown steadily apart since the sixteenth century. A brittiant and widely-read intellectual historian here attempts to reunite the two disciplines, examining the role of the novel in history and criticism

\section{LEGISLATORS AND INTERPRETERS \\ On Modernity, \\ Post-Modernity, and intellectuals}

By ZYGMUNT BAUMAN. After examining the historical conditions under which the modern world view. with its characteristic intellectual strategy was formed. Bauman discusses how that strategy was challenged, and partially supplanted. by an alternative "post-modern" view

\section{LITERATURE AND} ITS THEORISTS

A Personal View of

Twentieth-Century Criticism By TZVETAN TODOROV. Translated by Catherine Porter. Now available in English, this controversial work part history, part contession, part manifesto -is Todorov's bold statement of what literature is and what criticism should be.

$\$ 24.95$

\section{RE-FORMING}

\section{THE NARRATIVE}

Toward a Mechanics of Modernist Fiction

BY DAVID HAYMAN. In Re-forming the Narrative, Hayman deepens our understanding of the overarching and pervasive "modernist" style by exploring five characteristic narrative strategies, revealing their antecedents, identifying their governing mechanisms, and making clear their often subversive function in twentieth-century fiction. $\$ 24.95$

\section{HISTORICAL}

\section{UNDERSTANDING}

By LOUIS O. MINK. Edited by BRIAN FAY, EUGENEO. GOLOB, and RICHARD T. VANN. Louis O. Mink (1921-1983) was a leading theorist in the phitosophy of history. Historical Understanding, the first collection of his essays, addresses a number of important issues, including the distinctive nature of historical understanding; the relation of history and

fiction; and the cognitive status of narratives. $\$ 29.95$

See inside for more tittes of interest.

\section{Cornell University Press}

124 Roberts Place, Ithaca, New York 14850

THE POLITICAL RESPONSIBLITY

\section{OF THE CRITIC}

By JIM MEROD. In this provocative book, a scholar deeply committed to the belief that intellectuals must take an active part in the shaping of democratic institutions examines the role of the literary critic in loday's highly integrated but highly spe-

cialized consumer society. $\$ 24.95$

\section{DIALECTICAL \\ IMAGES}

Walter Benjamin's Theory of Literary Criticism

BY MICHAEL W. JENNINGS

Combining readings of Benjamin's texts with a close examination of the development of his theory of the work of art, Jennings reveals how Benjamin formulated a critical practice that was also an inquiry into epistemology and the philosophy of history. $\$ 24.95$

\section{SCENARIOS OF THE IMAGINARY}

Theorizing the

French Enlightenment

By JOSUE V. HARARI. Harari interprets the French Enlightenment in terms of the relationship between theory and the imaginary, and explores the paradox by which theories that purport to describe the real tack any dimension of reality. \$24.95

\section{KAIRONOMIA}

On the Will-to-Invent

BY ERIC CHARLES WHITE. in this elegantly written and iluminating speculative essay. White puts forth a view of interpretive invention derived from the sophistic movement of the Greek Enlightenment. \$18.95 